\title{
Proces apelatywizacji w ujęciu socjolingwistycznym na przykładzie eponimu "Karen" i jego funkcji w slangu amerykańskim
}

The process of appellativization in the sociolinguistic approach on the example of the eponym "Karen" and its function in American slang

Natalia PODLECKA ${ }^{1}$

Ateneum-Szkoła Wyższa w Gdańsku

\begin{abstract}
Streszczenie
Niniejsza praca poddaje analizie proces apelatywizacji eponimu Karen funkcjonującego w slangu amerykańskim. Powstawanie wyrazów odimiennych może mieć różne podłoża i różne przyczyny, jednak w przypadku wybranego przykładu mamy do czynienia ze zwrotem ilustrującym więcej niż jedno zjawisko socjologiczne. Badając definicję słowa Karen, można wskazać na trzy sfery życia Amerykanów, które podlegają wielu napięciom i emocjonalnym reakcjom. Pierwszą z nich sfera ekonomiczno-społeczna, związana z dużym rozwarstwieniem społecznym. Kolejną jest wciąż obecny problem $\mathrm{z}$ tolerancją rasową, a zwłaszcza demonizowaniem Afroamerykanów. Ostatnim omawianym elementem jest pandemia i jej wpływ na społeczeństwo amerykańskie.

Słowa kluczowe: eponim, apelatywizacja, Karen, kultura amerykańska
\end{abstract}

1 https://orcid.org/0000-0002-3329-782X

Ateneum-Szkoła Wyższa w Gdańsku, Wydział Neofilologiczny

n.podlecka@ateneum.edu.pl 


\section{Abstract}

This work analyses the process of appellativisation of the "Karen" eponym functioning in American slang. The formation of inflected words may have various grounds and reasons, but in the case of the chosen example, we are dealing with a phrase that illustrates more than one sociological phenomenon. By examining the definition of the word "Karen", it is possible to identify three spheres of American life that are subject to many tensions and emotional reactions. The first of them is the economic and social sphere, associated with high social stratification. Another is the problem of racial tolerance that is still present, especially the demonization of African Americans. The last element to be discussed is the pandemic and its impact on American society.

Keywords: eponym, appellativisation, Karen, American culture

\section{Wstęp}

Słowotwórstwo to obszerny i ciekawy dział językoznawstwa, który pozwala badaczom na rejestrowanie i analizowanie zmian zachodzących nieustająco w większości języków. Zmiany te najczęściej są odzwierciedleniem zmian społecznych, które mogą mieć różne podłoża, np. ekonomiczne, technologiczne, socjologiczne, itp. Niniejszy artykuł koncentruje się na jednym z elementów słowotwórstwa, jakim jest zjawisko apelatywizacji, czyli powstawania słów odmiennych, tj. eponimów. Proces ten chciałabym przedstawić na przykładzie eponimu "Karen", którego popularność i rozpoznawalność w Stanach Zjednoczonych, i nie tylko, wzrosła znacząco w ciągu ostatnich lat. Analiza tego relatywnie nowego słowa ma na celu przedstawienie złożoności i zróżnicowania społeczeństwa amerykańskiego pod względem rasowym i ekonomicznym, jak również wskazanie napięć obecnych wśród niektórych grup społecznych.

\section{Eponimy}

Pojęcie eponimu, wbrew brzmieniu samego leksemu, nie skrywa skomplikowanej treści, według Słownika języka polskiego PWN jest to "1. «wyraz lub wyrażenie utworzone od nazwy własnej; też: nazwa własna, od której je utworzono»" (eponim - Słownik języka polskiego PWN, b. d.). Jednak pomimo stosunkowo prostej definicji, sam proces apelatywizacji, czyli powstawania nowych eponimów, może zachodzić w różnym tempie i różnych okolicznościach. 
Sadowski (2013, za: Cieślikowa, 2006) przedstawia następującą propozycję podziału eponimów ze względu na przyczyny ich powstania:

1. Eponimy powstałe wskutek specyficznego sposobu zachowania się danej postaci w określonej sytuacji (np. cham, miłosierny Samarytanin);

2. Eponimy powstałe ze względu na określone cechy znanych postaci (chuligan, donżuan, herkules, lowelas, Ksantypa, Penelopa);

3. Eponimy związane z wiekiem niektórych sławnych osób (beniaminek, nestor, Matuzalem);

4. Eponimy nazwane od twórców, wynalazców, reprezentantów doktryn, firm, władców itp. (adidas, bloody mary, colt, dżul, mercedes, platoríski);

5. Eponimy powstałe lub nazwane od wyjątkowego miejsca (dżins, jakobini, tabasco, tweed);

6. Eponimy zainspirowane artykulacją i związanymi z nią skojarzeniami (np. Pcim, Wąchock, jako synonimy polskiego prowincjonalizmu) (s. 291-292).

Przedstawione powyżej typy tytułowych eponimów ukazują różnorodność tego zjawiska, a także jego zasięg, ponieważ część przedstawionych leksemów funkcjonuje nie tylko w języku polskim, ale także np. w języku angielskim. Wśród nich są na przykład takie jednostki jak: Samarytanin (ang. Samaritan), nestor, bloody mary, colt, tweed.

\subsection{Proces apelatywizacji}

Zdecydowanie jednym z najwyrazistszych czynników, mających wpływ na proces tworzenia i rozpowszechniania eponimów jest obecnie Internet, a w szczególności media społecznościowe. Język angielski wydaje się być najlepszym przykładem i zarazem obszarem do badań w tym zakresie, na co wpływają jego rozpowszechnienie oraz dostępność na całym świecie, jak również różnorodność kulturowa jego użytkowników. Nie bez znaczenia w związku ze szczególnym rozpowszechnieniem języka angielskiego jako języka komunikacji w świecie Internetu jest prężny rozwój Doliny Krzemowej w stanie Kalifornia w Stanach Zjednoczonych. Wpływ takich firm jak Google, Facebook czy Twitter nie tylko na sam język, ale na człowieka i społeczeństwo w ogóle, stał się niebagatelnym przyczynkiem do pochylenia się naukowców $\mathrm{z}$ wielu branż nad tą tematyką. Pod względem językowym obecność mediów 
społecznościowych bardzo pomaga badaczom, dostarczając im bogate przykłady języka użytego w praktyce.

Ciekawym elementem mediów społecznościowych są tzw. memy, czyli jak informuje Słownik Języka Polskiego PWN: "chwytliwa porcja informacji, zwykle w formie krótkiego filmu, obrazka lub zdjęcia, na którym umieszczono jakiś tekst, rozpowszechniana w Internecie"2. Jest to forma przekazywania informacji najchętniej używana przez ludzi młodych, chociaż nawet pokolenie boomersów potrafi zaskoczyć trafnym wykorzystaniem tego nośnika. W Polsce memy przyczyniły się do powstania i rozpowszechnienia eponimu Janusz, którego apelatywne użycie ,jest zjawiskiem na tyle nowym, że niepodobna go analizować w oparciu o dane Narodowego Korpusu Języka Polskiego" (Walkowiak, 2020, s. 3). Imię Janusz charakteryzuje „szczególny rodzaj Polaka”, który w następujący sposób ilustruje na podstawie zebranych danych internetowych Justyna Walkowiak (2020, s. 3): “jest to mężczyzna w średnim wieku lub starszy, otyły, z wąsami, ewentualnie z czerwoną twarzą, ubrany niegustownie, niemodnie i/lub nieestetycznie; latem nosi koszulkę na ramiączkach lub $\mathrm{w}$ miejscach publicznych paraduje $\mathrm{z}$ gołym torsem". Imię Janusz, które, co warto podkreślić za autorką, nie wywodzi się od żadnej konkretnej postaci historycznej, biblijnej, literackiej czy mitologicznej, zaczęło reprezentować stereotypowego Polaka, w znaczeniu zdecydowanie pejoratywnym, stając się rodzajem narodowej autokrytyki. Dodatkowo słowo zostało połączone $\mathrm{z}$ wizerunkiem jednego $\mathrm{z}$ ssaków naczelnych, tj. nosacza sundajskiego, co jest ciekawym zjawiskiem, biorąc pod uwagę fakt, że nie jest to gatunek rdzenny żyjący w Polsce. Okazuje się jednak, że połączenie to doskonale trafiło we wrażliwość odbiorców, ponieważ zarówno termin, jak i towarzyszący mu wizerunek nosacza sundajskiego wciąż $\mathrm{z}$ upodobaniem pojawiają się na stronach internetowych i stanowią już stały element polskiego doświadczenia, opartego na wartościującej komunikacji internetowej, szczególnie tej prowadzonej w mediach społecznościowych.

\section{Apelatywizacja eponimu Karen w Stanach Zjednoczonych}

Słowo Karen jest powszechnie używane w slangu amerykańskim od 2018 roku w celu opisania konkretnego rodzaju Amerykanki. Karen jest białą kobietą z klasy średniej, która zachowuje się roszczeniowo, zwłaszcza wobec pracowników fizycznych i niższych szczebli, i która wykorzystuje swoją

2 Definicja terminu mem patrz: Słownik Języka Polskiego PWN, online: https://sjp.pwn.pl/sjp/mem;5579327.html (dostęp 10.10.2021). 
pozycję zarówno w kontekście płci, jak i rasy, by zdominować mniejszości rasowe, takie jak Afroamerykanie czy Latynosi (Nagesh, 2000). ${ }^{3}$

Co ciekawe więc, pandemia koronawirusa, która wpłynęła na tak wiele aspektów życia ludzi nie tylko w Stanach Zjednoczonych, ale i na całym świecie, miała również wpływ na rozwój eponimu Karen, którego definicja została rozszerzona wraz z pojawieniem się nowej rzeczywistości. Zatem do poprzednich cech została dodana niechęć do szczepionek i noszenia maseczek, nawet w przypadkach odgórnych rządowych zaleceń, jak również zawierzanie teoriom spiskowym (Nagesh, 2020).

Jak widać na omawianym przykładzie konkretny eponim może być nośnikiem wielu informacji $\mathrm{w}$ kontekście całego społeczeństwa, choć w przypadku Karen kolejne znaczenia były dodawane wraz z szerzącą się popularnością samego terminu. Imię to nie było pierwszym, które pretendowało do zdobycia uznania na taką skalę. W slangu amerykańskim pojawiały się już inne jednostki, określające białą kobietę o roszczeniowym lub rasistowskim sposobie zachowania się, np. Permit Patty. Terminem Permit Patty nazwano kobietę, która zgłosiła służbom zażalenie na czarnoskóre ośmioletnie dziecko, które, chcąc zarobić na kieszonkowe, rozstawiło się przed swoim domem ze stoiskiem i sprzedawało butelki z wodą - zdaniem kobiety bez wymaganej licencji ${ }^{4}$ (ang. permit - zezwolenie, pozwolenie) (BBC Newsbeat, 2018). Inna kobieta, która z kolei zadzwoniła po policję, gdyż zaniepokoiło ją przyjęcie z grillem, urządzone przez czarnoskórych sąsiadów, została przez media nazwana $B B Q$ Becky (Nagesh, 2020). Zarówno imię "Patty", jak i "Betty" są najczęściej używanymi imionami wśród białych kobiet w stanach, dlatego też takie imiona szybciej tworzyły właściwą konotację. Do tej grupy można także zaliczyć imię "Karen”, które ostatecznie wygrało tę rywalizację dzięki potędze mediów społecznościowych.

W 2018 użytkownik serwisu internetowego reddit.com, o loginie Karmacop97, postanowił przekształcić historię rozwodu innego użytkownika

\footnotetext{
3 Fenomen Karen wyjaśnia Nagesh (2000) w swoim tekście zatytułowanym „What exactly is a 'Karen' and where did the meme come from?" w następujący sposób: "Karen" has, in recent years, become a widespread meme referencing a specific type of middle-class white woman, who exhibits behaviours that stem from privilege. To give some examples, "Karen" is associated with the kind of person who demands to "speak to the manager" in order to belittle service industry workers, is anti-vaccination, and carries out racist micro-aggressions, such as asking to touch black people's hair. Tekst dostępny online na stronie BBC: https://www.bbc.com/news/world53588201 (dostęp 11.09.2021).

${ }^{4}$ Tekst dostępny online na stronie BBC: https://www.bbc.com/news/newsbeat-44601668 (dostęp 11.09.2021).
} 
tworząc memy, oparte na ściśle określonym typie kobiety. Na tym etapie chodziło przede wszystkim o kobietę roszczeniową i pełną hipokryzji, ponieważ oryginalna Karen, która zainspirowała swojego męża do podzielenia się swoją historią $\mathrm{w}$ mediach społecznościowych, w związku z rozwodem odebrać miała mężowi wszystko, co tylko było możliwe, włącznie z dziećmi (Romano, 2020). Oczywiście zaistniałą sytuację interpretować można na wiele sposobów, mając do dyspozycji tylko takie wybiórcze i przedstawione subiektywnie informacje. W tym przypadku prawda okazała się jednak mniej relewantna niż sama potrzeba wyrażenia własnej frustracji. Frustracja ta wybrzmiała poprzez stereotypowe i uproszczone zilustrowanie charakteru kobiety, której przypisano cechy charakteru ogólnie przyjęte za negatywne. Co ciekawe, podobnie jak w przypadku polskiego Janusza, leksem Karen również została zobrazowany jej ironicznym przedstawieniem, jednak w tym przypadku najczęściej jest to zdjęcie z 2010 roku, przedstawiające Kate Gosselin, amerykańską celebrytkę i osobowość telewizyjną, w charakterystycznej fryzurze, tzn. blond włosach ściętych na "boba" (Nagesh, 2020). Dzięki powstaniu memu $\mathrm{z}$ Karen, słowo to zaczęło zyskiwać coraz większą popularność, o czym świadczy sam wzrost popularności użytkownika Karmacop97 w serwisie reddit.com, od 4000 obserwujących w 2018 do 435.000 w 2020 (Romano, 2020). Wraz ze wzrostem popularności eponim Karen zyskał nowy, dodatkowy wymiar semantyczny, a wszystkie omawiane definicje obrazują trzy kluczowe aspekty życia współczesnego społeczeństwa amerykańskiego, które chciałabym omówić głębiej: aspekt ekonomicznospołeczny, rasowy i problem pandemii.

\subsection{Aspekt ekonomiczno-społeczny w kontekście eponimu Karen}

W tym kontekście Karen jawi się jako przedstawicielka klasy wyższej-średniej, traktująca z góry każdego z niższych klas społecznych.

Ekonomista J.D. Foster definiuje 20 procent najlepiej zarabiających obywateli USA jako klasę o „wyższych dochodach” (upper income), dolne 20 procent jako „dochód niższy” (lower income), a pozostałe 60 procent populacji to zgodnie z jego podziałem tzw. klasa średnia (middle class). Przy takim rozróżnieniu roczne dochody gospodarstw domowych dla klasy średniej wahać się mają między 25.000 a 100.000 USD (OpenStax, 2017, s. 190; cytowane za Mason \& Sullivan, 2010). Klasa średnia w Stanach Zjednoczonych obejmować może zatem zarówno osoby zarabiające ok. 150 tys. Dolarów rocznie, jak i te, zarabiające 30 tys. (tamże). Jest to na tyle duża rozbieżność, że wymusiła ona kolejny podział, na tzw. klasę średnią wyższą i klasę średnią 
niższą. Ta pierwsza reprezentowana ma być przede wszystkim przez osoby o wyższym wykształceniu, najczęściej w zawodach takich jak prawnik, lekarz czy biznesmen. Do klasy średniej niższej należeć mają osoby o średnim wykształceniu bądź wyższym na poziomie licencjatu. Co ciekawe przedstawiciele tej drugiej warstwy społecznej są najczęściej pracownikami przedstawicieli pierwszej wymienionej grupy, co również ma wpływ na relacje między obiema grupami (OpenStax, 2017, s. 191-192). Eponim Karen opisuje tu kobietę $\mathrm{z}$ klasy średniej wyższej lub po prostu klasy średniej, która charakteryzuje się przede wszystkim zamiłowaniem do komfortu. Mimo, iż cecha ta nie musi być z zasady negatywna, w przypadku pejoratywnego użycia Karen jest ona wyolbrzymiona do groteskowej roszczeniowości i determinacji w działaniu nieadekwatnej do celu, który jest realizowany. Najlepszym przykładem zachowania typowego dla amerykańskiej Karen jest hasło, które pojawia się prawdopodobnie najczęściej $\mathrm{w}$ memach przedstawiających ten stereotyp: "I'd like to speak to a manager" czyli "Chciałabym rozmawiać $z$ kierownikiem”. To krótkie zdanie oznajmujące o charakterze roszczeniowym w wyraźny sposób obrazuje sytuację, w której osoba niezadowolona z usługi lub zakupionego produktu nie jest $\mathrm{w}$ stanie lub nie ma chęci rozwiązać problemu z pracownikiem pierwszej linii, czyli z przedstawicielem klasy średniej niższej, często innej narodowości bądź rasy. W tej sytuacji Karen okazuje swoją pogardę dla pracowników niższego szczebla, zakładając, że tylko $\mathrm{z}$ osobą z kadry kierowniczej jest w stanie porozmawiać rzeczowo i wyjaśnić sytuację.

Wraz z popularyzacją eponimu Karen, coraz częściej na stronach internetowych takich jak youtube.com czy 9gag.com, pojawiają się zdjęcia i krótkie filmy przedstawiające sytuacje, w których białe amerykańskie kobiety $\mathrm{w}$ agresywny i emocjonalny sposób spierają się z przedstawicielami różnych branż, często są nimi pracownicy restauracji lub marketów, w sposób niewspółmierny do szkód jakich doznały. Z pewnością przyczyniło się to do utrwalenia negatywnego stereotypu białej kobiety, gardzącej osobami z niższych sfer.

\subsection{Aspekt rasowy w kontekście eponimu Karen}

W tym kontekście Karen ukazana jest jako biała kobieta zawsze wyczulona i przygotowana na zagrożenie ze strony osób o innym kolorze skóry.

Temat rasizmu i zagadnienia związane $\mathrm{z}$ samym leksemem rasa stanowią

$\mathrm{w}$ Stanach Zjednoczonych niezwykle delikatną materię. Pomimo, iż od 1865 roku prawnie nie istnieje już niewolnictwo, a od 1964 nie ma już 
segregacji systemowej, napięcia na tle rasowym są wciąż faktem. Najdobitniej świadczą o tym wydarzenia z 25 maja 2020 roku, kiedy to George Floyd, 46-letni Afroamerykanin, został podczas interwencji policyjnej uduszony przez przytrzymującego go dłuższy czas policjanta. Cała sytuacja została nagrana przez świadków tego wydarzenia i w krótkim czasie, za pomocą mediów społecznościowych, obiegła cały świat, a w samych Stanach Zjednoczonych wywołała istną burzę i falę krytyki. Szczególne oburzenie wywołały wypowiadane przez aresztowanego frazy “I can't breathe” („Nie mogę oddychać”) oraz "Please I can’t breathe”. („Prosze, nie mogę oddychać”), które $\mathrm{w}$ zestawieniu $\mathrm{z}$ upowszechnionym obrazem przytrzymywanego siłą mężczyzny stały się podstawą do zbudowania całej dalszej narracji.

W związku z protestami i zamieszkami wywołanymi przez śmierć Floyda, sprawa zaczęła być szerzej znana i dogłębniej badana, zarówno pod kątem postępowania obecnych na miejscu funkcjonariuszy policji, jak i historii samej ofiary. Niezależnie jednak od interpretacji własnych pewnych zagadnień czy subiektywnej oceny całej zaistniałej sytuacji, pewne fakty wydają się odbiorcy niepodważalne: białoskóry policjant zabił czarnoskórego mężczyznę. Taki przekaz stanowi znaczne uproszczenie i ujednolica nadawaną informację reakcja ogółu społeczeństwa zatem była znamienna, a wywołana fala protestów stała się tematem szeroko zakrojonej debaty mediów na całym świecie.

Należy wziąć pod uwagę także fakt, iż przy tej okazji w celach dezinformacyjnych pojawiła się nieprawdopodobna ilość nieprawdziwych lub częściowo nieprawdziwych informacji (tzw. fake newsów) ${ }^{6}$. W tych przypadkach osoby trzecie manipulowały informacjami, by wzbudzić określony efekt, co jednak nie wyklucza postawienia tezy, iż napięcia na tle rasowym w Stanach Zjednoczonych są wciąż zjawiskiem bardzo żywym. Stąd też wynika potrzeba dla kolejnej charakterystyki eponimu Karen, czyli właśnie kobiety uprzedzonej rasowo. Dobrym przykładem ilustrującym tę kolejną ciemną stronę Karen jest sytuacja przytoczona przez Ashithę Nagesh (2020), która

${ }^{5}$ Podaję za Hauser (2020). „FBI to Investigate Arrest of Black Man Who Died After Being Pinned by Officer". The New York Times, Online:

https://web.archive.org/web/20200526143016/https://www.nytimes.com/2020/05/26/us/minneap olis-police-man-died.html (dostęp 15.10.2021).

6 Według badania przeprowadzonego przez Zignal Labs największą dezinformacją, będącą wynikiem protestów, było nieuzasadnione twierdzenie, iż za zamieszki i grabieże odpowiedzialność ponoszą aktywiści Antify: z 873.000 przeanalizowanych fałszywych newsów związanych z protestami aż w 575.800 pojawiły się wzmianki o Antifie (podaję za Alba, 2020) „Misinformation About George Floyd Protests Surges on Social Media”, Online:

https://web.archive.org/web/20200612150326/https://www.nytimes.com/2020/06/01/technology/ george-floyd-misinformation-online.html (dostęp 15.10.2021). 
przypadkowo wydarzyła się dokładnie tego samego dnia co śmierć Georga Floyda, tj. 25 maja 2020 roku. W nowojorskim Central Parku, czarnoskóry ornitolog-amator, Christian Cooper, poprosił białoskórą kobietę, Amy Cooper, o to, by złapała swojego psa i prowadziła go na smyczy. W odpowiedzi kobieta zadzwoniła na numer alarmowy 911, mówiąc, że: "jest tu Afroamerykanin, który zagraża mojemu życiu" (ang.: "there's an African-American man threatening my life") (Nagesh, 2020). Niestety dla pani Cooper, dzisiejszym zwyczajem, cała sytuacja została nagrana, a ona sama dostała od prasy przydomek Central Park Karen (Nagesh, 2020).

Demonizowanie czarnoskórych to jedna z czarnych kart historii i kultury amerykańskiej, która ma korzenie $\mathrm{w}$ samych początkach powstawania tego państwa. Od początku niewolnictwa ważne dla białych panów było to, żeby przestawiać niewolników jako podgatunek człowieka, ponieważ ułatwiało im to usprawiedliwienie swojego zachowania względem nich. Wśród negatywnych stereotypów pojawił się również mówiący o tym, że czarnoskórzy mężczyźni pragną białych kobiet. Obraz ten widoczny jest nawet w filmie "Narodziny narodu" w reżyserii D. W. Griffitha z 1915 roku, w którym pościg niewolnika za białą młodą dziewczyną doprowadza ją do śmierci $\mathrm{w}$ wyniku upadku $\mathrm{z}$ urwiska. Oglądając te sceny dzisiaj, możemy zobaczyć bliską korelację między wizją Griffitha, a zachowaniem Amy Cooper, bo, mimo że Griffith mógł mieć inne intencje, a opisane powyżej sceny z jego filmu wydają się współczesnemu odbiorcy groteskowe, są w sposób boleśnie oczywisty przerysowane. Tak też można opisać zachowanie Amy Cooper, czyli przysłowiowej Central Park Karen.

\subsection{Aspekt pandemii w kontekście eponimu Karen}

Karen ukazana jako „antyszczepionkowiec”, walcząca o prawo do nienoszenia maseczek w przestrzeni publicznej.

Pandemia koronawirusa miała i wciąż ma ogromny wpływ na społeczeństwa na całym świecie, społeczeństwo amerykańskie nie jest tu żadnym wyjątkiem. Pierwszy raz za życia większości współczesnych ludzi pojawiło się zagrożenie o skale światowej. Z punktu widzenia jednostki wpływ ten polegał na nagłych zmianach $\mathrm{w}$ codziennym funkcjonowaniu zarówno jednostki w swej przestrzeni prywatnej, jak i jednostki w społeczeństwie. Przymusowy odgórny „lockdown” zmusił nauczycieli i uczniów do przejścia na nauczanie zdalne, wielu pracodawców i pracowników do pracy z domu, a wielu innych do zredukowania miejsc pracy lub zrezygnowania $\mathrm{z}$ niej całkowicie. Kolejnym wymogiem, który według niektórych ograniczać ma wolność 
jednostki, jest noszenie maseczek $\mathrm{w}$ przestrzeni publicznej. Choć $\mathrm{w}$ wielu krajach azjatyckich stosuje się maseczki od wielu lat, w Stanach Zjednoczonych niemal od momentu wprowadzenia rozporządzeń dotyczących obowiązku ich noszenia zaczęły pojawiać się protesty, zarówno grupowe, jak i w formie obywatelskiego nieposłuszeństwa. Właśnie ten drugi rodzaj protestów jest reprezentowany przez eponim Karen. Tak jak w przypadku zachowań rasistowskich, tak i w przypadku reakcji agresywnej i emocjonalnej, niewspółmiernej do sytuacji, możemy znaleźć wiele przykładów na takie zachowania także wśród białych Amerykanek, które właśnie ten zwrot mają reprezentować. Kolejnym związanym $\mathrm{z}$ tym elementem zmieniającej się rzeczywistości jest obowiązek szczepień, który szybko stał się tematem polaryzującym społeczeństwo amerykańskie. Tu ujawnia się negatywny aspekt mediów społecznościowych, jakim są fałszywe informacje, czyli wspomniane już "fake newsy", które często popierane są nieprawdziwymi danymi w celu wywołania silnej reakcji emocjonalnej u odbiorców. Rezultatem fake newsów są pojawiające się masowo teorie spiskowe, które w ostatnich latach zyskały znacznie na popularności. Problem fake newsów ukazywać może dodatkowo na pewien problem edukacji i amerykańskiej dojrzałości społecznej, ponieważ ich popularność, szybkość z jaką docierają do tak wielu odbiorców oraz siła, z jaką oddziaływają na nich świadczyć mogą o relatywnie niskim poziomie umiejętności krytycznego myślenia i weryfikacji informacji u części odbiorców. Karen ilustruje ten problem w sposób groteskowy i karykaturalny, co może mieć negatywne skutki, ponieważ niewiedzę i ignorancję powinno się wspierać wiedzą, a nie uczynić je wyłącznie przedmiotem kpin.

\section{Wnioski}

Eponim Karen zagościł na stałe w slangu amerykańskim. Samo hasło "Karen meme" wpisane w wyszukiwarkę Google wygenerowało około 85700000 wyników, a jak już zostało wspomniane, materiały dotyczące Karen to nie tylko zdjęcia, ale również filmy i nagłówki gazet. Imię to stało się synonimem białej kobiety traktującej $\mathrm{z}$ pogardą innych, przepełnionej rasistowskimi przekonaniami i podatnej na wpływ fake newsów czy teorii spiskowych. Odbiór tak nacechowanego leksemu nie może być zatem inny niż negatywny. To pejoratywne nacechowanie słowa Karen spowodowało, że zaczęto je analizować pod kątem seksizmu, w związku z popularyzowaniem negatywnego stereotypu na temat kobiet (Nagesh, 2020). Jednak bez względu na odbiór definicji tego nowego eponimu, pozostaje on odzwierciedleniem problemów ekonomiczno-społecznych, rasowych i pandemicznych współczesnego 
społeczeństwa amerykańskiego. W tym przypadku proces apelatywizacji zachodzi "wskutek specyficznego sposobu zachowania się danej postaci w określonej sytuacji” (Sadowski, 2013, za: Cieślikowa, 2006). W pewnym uproszczeniu można zatem skonstatować, iż do pojawienia się Karen we współczesnej postaci przyczyniły się białe Amerykanki z klasy średniej, niezależnie od ich własnego podejścia do tego zjawiska.

\section{BIBLIOGRAFIA}

OpenStax (2017). Social Stratification and Mobility in the United States. In: Introduction to Sociology 2e. (s. 183-204). Download for free at https:/openstax.org/details/ books/introduction-sociology-2e. (dostęp 15.09.2021).

Sadowski, M. M. (2013). Eponimy jako sposób wzbogacania leksyki. Acta Erasmiana V, 5 Varia, 289-308. Wrocław: Wydział Prawa, Administracji i Ekonomii Uniwersytetu Wrocławskiego.

Skudrzyk, A. \& Urban, K. (2002). Mcdonaldyzacja, bigbrotheryzacja, czyli eponimy współczesne - norma ortograficzna i uzus. W: H. Synowiec (red.), W kręgu zagadnień dydaktyki języka i literatury polskiej: księga jubileuszowa dedykowana Profesorowi Edwardowi Polańskiemu (s. 258-263).

Walkowiak, J. B. (2020). Jeszcze o apelatywizacji imienia Janusz. Studia z Filologii Polskiej i Słowiańskiej, 55, Article 1879. https://doi.org/10.11649/sfps.1879

\section{Źródła internetowe}

Alba, D. (2020, 1 czerwca), „Misinformation About George Floyd Protests Surges on Social Media". The New York Times. Online: https://web.archive.org/web/20200612150326/ https://www.nytimes.com/2020/06/01/technology/george-floyd-misinformationonline.html (dostęp 15.10.2021).

Hauser, Ch. (2020, 26 maja). „FBI to Investigate Arrest of Black Man Who Died After Being Pinned by Officer". The New York Times, Online: https://web.archive.org/ web/20200526143016/https://www.nytimes.com/2020/05/26/us/minneapolis-police-mandied.html (dostęp 15.10.2021).

Nagesh, B. A. (2020, 30 lipca). What exactly is a 'Karen' and where did the meme come from? BBC News. https://www.bbc.com/news/world-53588201

Romano, A. (2020, 5 lutego). Karen: The anti-vaxxer soccer mom with speak-to-the-manager hair, explained. Vox. https://www.vox.com/2020/2/5/21079162/karen-name-insultmeme-manager (dostęp 15.10.2021).

Słownik języka polskiego PWN. (b. d.). Słownik języka polskiego PWN. Online: https://sjp.pwn.pl (dostęp 15.09.2021). 
